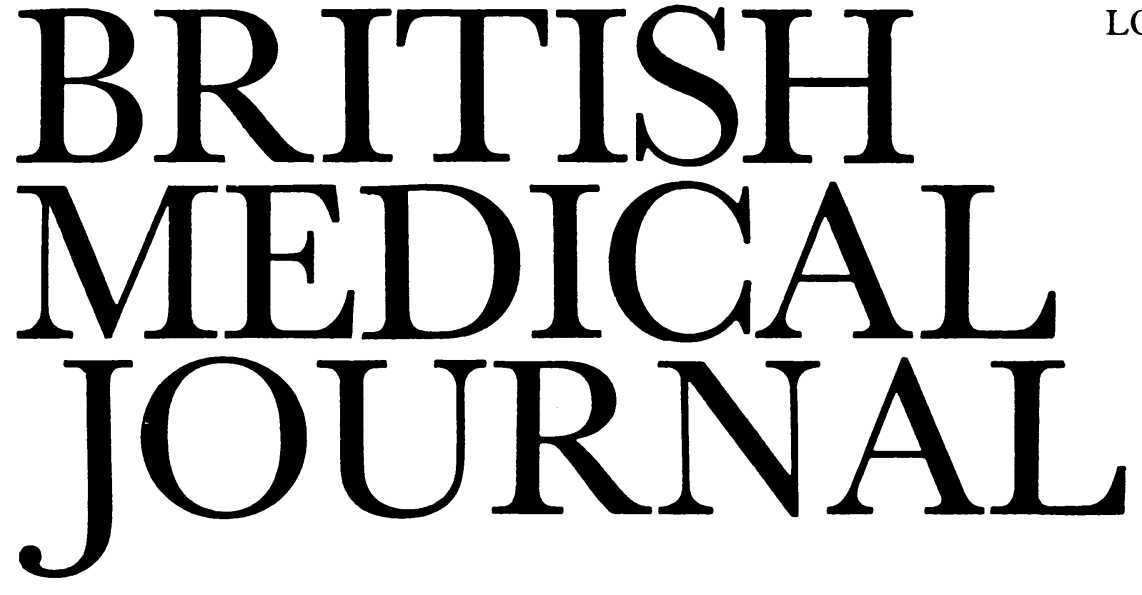

LONDON, SATURDAY 1 NOVEMBER 1986

\title{
Relapse of duodenal ulcer: does it matter which drug is used in initial treatment?
}

Duodenal ulcers recur within a year in $80-90 \%$ of patients treated initially with $\mathrm{H}_{2}$ antagonists, ${ }^{1-8}$ and evidence now exists that relapse rates may be lower after treatment with other ulcer healing drugs. Moshal postulated in 1978 that relapse rates might be lower after treatment with tripotassium di-citrato bismuthate (Moshal MG, Sixth World Congress of Gastroenterology, Madrid, 1978), and in a double blind prospective study we showed that this was indeed so. ${ }^{9}$ McLean and others ${ }^{10}$ have concluded that this may also be true for other ulcer healing drugs, including antacids, ${ }^{11}$ anticholinergics, ${ }^{12}$ antacid and anticholinergic combinations, ${ }^{13}$ carbenoxolone,${ }^{14}{ }^{15}$ sucralfate, ${ }^{16}$ and trithiozine. ${ }^{1718}$

Evidence for a reduction in relapse rate relative to cimetidine is not, however, strong for most of these agents individually. The studies have often been small, and the differences have also been small, either failing to reach significance or doing so only transiently. For example, Hansky and others claimed no significance for the difference in relapse rates that they observed in a small study of antacids against cimetidine, ${ }^{11}$ and larger studies have found no difference. ${ }^{19} 20$ The strength of the argument of McLean and others $^{10}$ is, however, that when an appreciable difference in relapse rates is observed it is consistently in favour of the comparative agent and to the detriment of cimetidine.

Only in the case of tri-potassium di-citrato bismuthate is there sufficient evidence for a single drug that the effect is real. Although our initial study was not immediately confirmed, ${ }^{21}$ four subsequent trials ${ }^{22-25}$ have shown lower relapse rates after tri-potassium di-citrato bismuthate than after an $\mathrm{H}_{2}$ antagonist. The more recent of these studies ${ }^{23-25}$ strengthen the case made by McLean and others and extend it to include ranitidine, which is followed by a similar relapse rate to cimetidine. The consistency of the results leaves little doubt that the phenomenon is genuine, and in a further trial recurrence rates were similar in patients maintained on cimetidine and those given only a short course of tripotassium di-citrato bismuthate to induce healing. ${ }^{26}$

Combining results from the six studies showed that $85 \%$ of patients treated with $\mathrm{H}_{2}$ antagonists relapse within a year compared with $59 \%$ of those treated with tri-potassium dicitrato bismuthate. ${ }^{91-25}$ Combining data from clinical trials is unreliable, but this is the best available quantitative estimate of the difference between the treatments. Because duodenal ulceration is so common even a difference of about $25 \%$ has important implications. Using life table analysis, however, probably underestimates the real difference between the treatments in terms of morbidity, time, and cost because patients who relapse are not (usually) dead. They are simply withdrawn from the trial and require further treatment, which will often be another course of drugs or some form of maintenance. Maintenance treatment is effective ${ }^{2728}$ but because of the cost is likely to be reserved for patients who relapse rapidly and predictably and for certain high risk groups.

We have applied an analysis similar to that of McLean and others ${ }^{10}$ to the data from the six studies ${ }^{921-25}$ and calculated the relapse rates after healing with an $\mathrm{H}_{2}$ antagonist $(17 \%$ a month) and with tri-potassium di-citrato bismuthate $(7 \%$ a month). Using these rates we have investigated the implications of a policy of repeated courses of treatment with the same agent-either an $\mathrm{H}_{2}$ antagonist or tri-potassium dicitrato bismuthate-when a patient relapses. After a short time a steady state is reached in which $19 \%$ of the $\mathrm{H}_{2}$ antagonist group are on treatment but only $10 \%$ of the tripotassium di-citrato bismuthate group. Twice as much $\mathrm{H}_{2}$ antagonist will thus be used, which would double the costs with cimetidine and triple them with ranitidine at current non-contract prices. Furthermore, at any time more patients on $\mathrm{H}_{2}$ antagonists have an ulcer, although they will not necessarily be symptomatic.

This model may not reflect accurately clinical practice and may apply more to the artificial context of the clinical trial. Nevertheless, it probably gives a better idea of clinical practice than the usual life table analysis. Outside clinical trials patients who undergo asymptomatic relapse are unlikely to be diagnosed or treated. This will reduce the overall costs of drug treatment, but the differential costs may still apply unless asymptomatic relapse is much less common after tri-potassium di-citrato bismuthate than after an $\mathrm{H}_{2}$ antagonist.

The reason for the difference in relapse rates is unknown. The notion that $\mathrm{H}_{2}$ antagonists heal more "difficult" ulcers that are also more prone to relapse ${ }^{29}$ is not tenable since the healing rates in the six studies were actually slightly higher with tri-potassium di-citrato bismuthate than with the $\mathbf{H}_{2}$ antagonists. Rapid relapse after an $\mathrm{H}_{2}$ antagonist might be explained by rebound hypersecretion secondary to previous suppression of acid secretion leading to hypergastrinaemia and increased parietal cell mass. Although increases in serum 
gastrin concentration during treatment with $\mathrm{H}_{2}$ antagonists have often been reported, there is little evidence of rebound hypersecretion and increased parietal cell mass. ${ }^{30}$ Recently, however, increased sensitivity of the parietal cell after ranitidine treatment to the submaximal and more physiological stimulus of simulated feeding has been reported. ${ }^{31}$

The difference in relapse rates may relate to the duodenal mucosal cell failing to return to normal after an $\mathrm{H}_{2}$ antagonist but not after tri-potassium di-citrato bismuthate. ${ }^{32}$ This requires confirmation, and even if true the mechanism remains to be determined. The relation between Campylobacter pyloridis, gastritis, and peptic ulceration might be relevant. ${ }^{33}$ Tri-potassium di-citrato bismuthate seems to remove Campylobacter pyloridis from gastric mucus whereas $\mathrm{H}_{2}$ antagonists do not. ${ }^{34} \mathrm{~A}$ further suggestion ${ }^{35}$ is that because of accumulation within the body bismuth continues to be excreted after tri-potassium di-citrato bismuthate is stopped. ${ }^{36}$ If correct this would imply a systemic and not just a local effect on ulcer healing. It also raises the spectre of bismuth encephalopathy, but this has not been reported with tri-potassium di-citrato bismuthate, which is recommended for four to eight week courses to heal ulcers and not for prolonged maintenance.

The higher relapse rates after healing with $\mathrm{H}_{2}$ antagonists compared with tri-potassium di-citrato bismuthate (and perhaps other agents) is now well established and should probably influence prescribing. Furthermore, a large scale trial to test the predictions of our model seems worth while.

J PAul Miller

Consultant gastroenterologist E BRIAN FARAGHER Senior medical statistician

Department of Medicine,

University Hospital of South Manchester,

Manchester M20 8LR

Correspondence to: Dr Miller.

We are grateful to Professor $\mathrm{G}$ Bianchi Porro for allowing us to use his full data currently being prepared for publication.

1 Bodemar G, Walan A. Maintenance treatment of recurrent peptic ulcer by cimetidine. Lancet 1978;i:403-7.

2 Gray GR, Smith IS, MacKenzie I, Gillespie G. Long term cimetidine in the management of severe ulcer dyspepsia. Gastroenterology 1978;74:397-401.

Blackwood WS, Maudgal DP, Northfield TC. Prevention by bedtime cimetidine of duodenal ulcer relapse. Lancet 1978; ;:626-7.

4 Gudmand-Hoyer E, Jensen KB, Krag E, et al. Prophylactic effect of cimetidine in duodenal ulcer disease. BrMed f 1978;i: 1095-7.

5 Dronfield MW, Batchelor AJ, Larkworthy W, Langman MJS. Controlled trial of maintenance cimetidine treatment in healed duodenal ulcer: short and long-term effects. Gut 1979;20:526 30

6 Hetzel DJ, Shearman DJC, Hecker R, Sheers R. Prevention of duodenal ulcer relapse by cimetidine. A one year double blind trial. Med f Aust 1979;i:529-31.

Hansky J, Korman MG. Long-term cimetidine in duodenal ulcer disease. Dig Dis $\mathrm{Sci}$ 1979;24:465-7.

8 Boyd EJS, Wilson JA, Wormsley KG. Safety of ranitidine maintenance treatment for duodenal ulcer Scand f Gastroenterol 1984;19:394-400.

9 Martin DF, Hollanders D, May SJ, Ravenscroft MM, Tweedle DEF, Miller JP. Difference in relapse rates of duodenal ulcer after healing with cimetidine or tripotassium dicitrato bismuthate. Lancet 1981;i:7-10.

10 McLean AJ, Harrison PM, Ioannides-Demos L, Byrne AJ, McCarthy P, Dudley FJ. The choice of ulcer healing agent influences duodenal ulcer relapse rate and long-term clinical outcome. Aust N Z Med F 1985;15:367-74

11 Hansky J, Korman MG, Schmidt GT, Stern AI, Shaw RG. Relapse of duodenal ulcer after healing with cimetidine or Mylanta II. Gastroenterology 1980;78:1179.

12 Vezzadini P, Sternini C, Bonora G, Botti PL, Lugli C, Labo G. Relapse rates of duodenal ulcer after healing with pirenzepine or cimetidine: a double blind study. Scand $\mathcal{f}$ Gastroenterol 1982;17(suppl 78): 100 .

13 Strom M, Gotthard R, Bodemar G, Walan A. Antacid /anticholinergic, cimetidine and placebo in the treatment of active peptic ulcers. Scand $\mathcal{J}$ Gastroenterol 1981;16:593-602.

14 Guslandi M, Cambielli M, Titobello A. Carbenoxolone maintenance in cimetidine-healed patients. Scand 7 Gastoenterol 1980;15:369-71.

15 Reed PI, Vincent-Brown A, Cook PJ, Colaco CB, Perks S, Baron JH, Jewell DP. Comparative study of carbenoxolone and cimetidine in the management of duodenal ulcer. Acta Gastroenterol Belg 1983:46:459-68.

16 Marks IN, Wright JP, Lucke W, Girdwood AH. Relapse rates after initial ulcer healing with sucralfate and cimetidine. Scand $\mathcal{F}$ Gastroenterol 1982;17:429-32.

17 Diaz FG. Short-and long-term effects of trithiozine and cimetidine in duodenal ulcer. Current Therapeutic Research 1981;29:853-65.
18 Tomassetti P, Stanghellini E, Bonora G, Vezzadini P, Labo G. Comparative trial on healing and relapse of duodenal ulcer treated with trithiozine or cimetidine. Current Therapeutic Research 1981;29:517-23.

19 Center for Ulcer Research and Education (CURE). Is duodenal ulcer recurrence more common after cimetidine treatment? Gastroenterology 1980;78:1152.

20 Ippoliti A, Elashoff J, Valanzuela J, et al. Recurrent ulcer after successful treatment with cimetidine or antacid. Gastroenterology 1983;85:875-80

21 Kang JY, Piper DW. Cimetidine and colloidal bismuth in treatment of chronic duodenal ulcer. Digestion 1982;23:73-9.

22 Shreeve DR, Klass HJ, Jones PE. Comparison of cimetidine and tripotassium dicitrato bismuthate in healing and relapse of duodenal ulcers. Digestion 1983;28:96-101.

23 Bianchi Porro G, Barbara L, Cheli R, Dal Monte PR, Mazzaca G. Comparison of tripotassium dicitrato bismuthate (TDB) tablets and ranitidine in the healing and relapse of duodenal ulcers. Gut 1984;25:A565.

24 Lee FI, Samloff IM, Hardman M. Comparison of tri-potassium di-citrato bismuthate tablets with ranitidine in healing and relapse of duodenal ulcers. Lancet 1985; ; 1299-1302.

25 Hamilion I, O'Connor HJ, Wood NC Bradbury I, Axon ATR. Healing and recurrence of duodenal ulcer after treatment with tripotassium dicitrato bismuthate (TBD) tablets or $\mathrm{O}$ cimetidine. Gu 1986;27:106-110.

26 Bianchi Porro G, Lazzaroni M, Petrillo M, De Nicola C. Relapse rates in duodenal ulcer patients formerly treated with bismuth subcitrate or maintained with cimetidine. Lancet 1984;ii:698. 7 Pounder RE. Model of medical treatment for duodenal ulcer. Lancet 1981;i:29-30.

28 Sonnenberg A. Comparison of different strategies for treatment of duodenal ulcer. $\mathrm{Br} \mathrm{Med} \mathrm{F}$ $1985 ; 290: 1185-7$.

29 Yeomans ND. Relapse of duodenal ulcers after cimetidine treatment: idol "indecently" assaulted. Aust $N Z$ Med f 1985;15:291-2.

30 Mohammed R, Holden RJ, Hearns JB, McKibben BM, Buchanan KD, Crean GP. Effects of eight weeks' continuous treatment with oral ranitidine and cimetidine on gastric acid secretion, pepsin secretion, and fasting serum gastrin. Gut 1983;24:61-6.

Frislid K, Aadland E, Berstad A. Augmented postprandial gastric acid secretion due to exposure to ranitidine in healthy subjects. Scand 7 Gastroenterol 1986;21:119-22.

Mosh comparison of treatment with cimetidine and DeNol. Scand I Gastroenterol 1979;14(suppl i 54):48-51.

33 Marshall BJ, McGechie DB, Rogers PA, Glancy RJ. Pyloric campylobacter infection and gastroduodenal disease. Med $f$ Aust 1985;142:439-44.

34 Lambert JR, Hansky J, Davidson A, Pinkard K, Stockman K. Campylobacter-like organisms (CLO)-in vivo and in vitro susceptibility to antimicrobial and antiulcer therapy. Gastroenterology 1985;88:1462.

35 Pounder RE. Duodenal ulcers that will not heal. Gut 1984;25:697-702.

36 Hamilton I, Worsley BW, O'Connor HJ, Axon ATR. Effects of tripotassium dicitrato bismuthate tablets or cimetidine in the treatment of duodenal ulcer. Gut 1983;24:1148-51.

\section{A plan for paediatric surgery}

The Department of Health and the surgical establishment have now accepted the need to improve the general surgical care of children in Britain. Although all but one of the health regions has a specialist paediatric and neonatal surgical unit, most children are treated in district hospitals by general $\stackrel{\circ}{\circ}$ surgeons. Furthermore, although the number of consultant $\overrightarrow{\vec{B}}$ paediatric surgeons has recently increased, paediatric sur- $\frac{9}{3}$ gery has been classified as a shortage specialty. In the past $\supset$ surgical trainees have been unwilling to contemplate a career in paediatric surgery because of the limited number of consultant posts, and they have, indeed, been actively discouraged from doing so by those already within the $\dot{\circ}$ specialty. The signs are now that this restrictive attitude will $\stackrel{3}{.}$. change.

Despite present difficulties, Britain has led the way in paediatric surgery, and on $\mathrm{p} 1156$ Jones describes some of $\frac{9}{5}$ what has been achieved as well as discussing what more $\tilde{N}$ might be done. The British Association of Paediatric Sur- $\rightarrow$ geons was founded in 1954 and was the first such association in the world. It continues to have a large international $N$ membership. One probable cause of the delay in expansion of $\mathcal{W}_{\mathfrak{N}}$ the specialty in Britain has been the difficulty in defining the $\overline{2}$

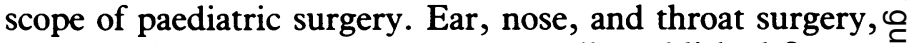
orthopaedics, and neurosurgery were all established first as specialties, and plastic surgery emerged at about the same + time as paediatric surgery - soon after the second world war. $\overline{0}$ The work of paediatric surgeons varied depending on what $\stackrel{\otimes}{\circ}$ other specialist surgeons were available, but the model of $\stackrel{\vec{D}}{\overrightarrow{0}}$ pioneers such as Denis Browne, whose repertoire covered the full range of children's surgery, was unlikely to be appropriate for most.

The council of the British Association of Paediatric . 